\title{
Narrative medicine in medical diagnosis
}

\section{Medicina narrativa en el diagnóstico médico}

\author{
Raúl Pino Andrade ${ }^{1,2,3}$ \\ haldopino@hotmail.com
}

1 Universidad de Cuenca, Facultad de Ciencias Médicas. Cuenca, Ecuador 2 Hospital Vicente Corral Moscoso. Cuenca, Ecuador, 3 Clínica Santa Ana, Cuenca, Ecuador

Modernity has brought with it a series of scientific advances that, in the medical field, have improved not only the diagnosis and treatment of diseases, but also the quality of life of patients. This is undeniable. It is enough to carry out an exercise of imagination and place our life in two different historical settings: first the Renaissance, and second the XXI century or contemp*orary era. Leaving cultural or historical affinities asi de, to the question: In which of these historical periods would you like to live? The most prudent answer is very likely: now, in this century. The advances of medicine can be traced historically, we cannot think about it without thinking in Vesalius, or Paré, and many others; however, it is true that the history of medicine accelerated markedly in the 20th century.

Citation: Pino AR. Colomb Med (Cali). 2020; 51(1):e4339. http://doi. org/10.25100/cm.v51i1.4339

Copyright: ( 2020 . Universidad del Valle.

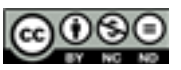

Corresponding author: Raúl Pino Andrade. Universidad de Cuenca, Facultad de Ciencias Médicas. Cuenca, Ecuador e-mail: haldopino@ hotmail.com

Although it is true that in just over a hundred years the greatest scientific discoveries have been made in all fields of knowledge, modernity has also meant a change in time itself. Everything unfolds at previously unimaginable speeds: material and knowledge production, teaching and learning, communication and interpersonal relationships. The latter point should be highlighted, and the changes due to the acceleration of the relationship between doctors and their patients should be pointed out on time. It is as if life should climb the assembly line and obey a Fordist logic. It must be recognized that the acceleration of certain aspects is significant, such as the expansion of diagnostic tests, creation of procedures and medications, immediate response to emergencies, among others. But all these advantages seem to carry with them, as a current, all areas of life including what must necessarily be paused. The slogan seems to be "produce more and more in less time". We must be productive, in order to be "better". In terms of the popular and productive philosopher, Byung-Chul Han, we are prey to a "Performance Society" ${ }^{1}$.

Health personnel, and doctors in particular, have surrendered their practice, without further question, to this slogan. Health institutions themselves, in their public or private logic, behave in a utilitarian way. Their goal is to have maximum returns, which translates into "better" statistics or higher incomes. A certain number of patients must be attended per hour, which makes the service time provided shorter and shorter. The patient is hardly examined and, in return, a battery of both laboratory and imaging tests is requested to make the diagnosis. Of course, this is not strange to those who do it, because in medical schools they teach them, or rather, they train them, to pay primary attention to the signs and symptoms of an illness. Little or nothing is devoted to learning strategies to access the patient's experience and internal world. On occasions when this is possible, we can find stories like the one Paco Maglio points out:

On one occasion, an old lady (the diminutive is affectionate) asked me to take her pulse. I looked at the cardioscope, and without accepting her request, I told her: "Don't worry, Grandma, you are 80, you are very well." But she kept asking me to take her pulse, and at her insistence I asked her why, since the machine was very reliable. She replied: "It is that nobody touches me here." We palpated her, but we did not touch her ${ }^{2}$. 
What does this observation imply? That perhaps we have lost something important in the doctor-patient relationship. Many times, in the areas of health, one acts with a very technical vision, using what the Greeks called tekne, that is, putting into play the knowledge and skills to heal the patient. This is morally correct, it is done well, but it has been forgotten that the patient is more than corporality, and that is when one must act as a doctor, combining the ability to heal (tekne), with the attitude of caring (medeos). Both the cardioscope and touching the patient are important. On this, there is the ancient Latin maxim, which is almost a medical code of honour: "medicus: vir bonus, plen humanitas, medendi peritus" that is: "doctor: good person, full of humanity, proficient in the art of healing" ${ }^{3}$.

To return to a more comprehensive vision of the patient, Narrative Medicine a , was developed. This term was coined by Dr. Rita Charon and with it, it is intended to generate a complementary vision to modern orthodoxy (corporalism). This narrative practice involves two movements: the first, a medical practice imbued with narrative skills that allow the doctor to recognize, absorb, interpret and be moved by patients' stories, always under a framework of respect towards the person affected by the disease; the second, to nurture medical professionals with the experiences resulting from this approach to the patient ${ }^{4}$.

To achieve this, doctors will need, in most cases, humility, to step down from "their seat" or "pedestal" from where they exercise power, to take a new position ${ }^{5}$.As Oliver Sacks stated:

"Doctors cannot penetrate into the domains of the incommunicable (or of what is extremely difficult to communicate) unless they become a traveling companion of their patients, accompanying them on their explorations, constantly moving in their company and discovering with them a lively, exact and figurative language that allows them to communicate what seemed incommunicable" ${ }^{\text {. }}$.

In other words, looking for a common language implies building bridges between doctors and patients, sometimes joining the stream and other times the abyss that separates them. This does not mean being the patient, appropriating their pain, in which case the medical activity would noticeably decrease, but knowing them. You must reduce the shield $\underline{b}$ to find a state of empathy:

Doctors should not see patients as impersonal objects, nor should they identify themselves with them, nor should they turn it into a projection of themselves, but should proceed through sympathy or empathy, advance in the company of patients, sharing their experiences, their thoughts and feelings, that is, the intimate concepts that make up their behavior. They must feel (or imagine) what their patients feel without ever losing their sense of themselves, and they must live simultaneously in two frames of reference and make it easier for patients to do the same ${ }^{6}$.

The use of the narrative technique in the field of medical education aims to bring that relegated language back. This strategy has shown positive results, not only to strengthen the doctorpatient relationship, but to improve the clinical analysis of the cases studied, and better understand the diagnosis, prognosis and treatment of the disease. In addition, with it, it is possible to improve the participation of decision-making processes shared with the patient ${ }^{7-4}$. So, it is worth using the medical narrative as a complement to the formal medical history, considering that both are complementary rather than antagonistic ${ }^{8}$.

You can think of some authors in addition to Dr. Charon if you are seeking to explore this approach, which, with different names, is present in various bibliographies. Going back in time we can find the figure of Gregorio Marañon who owes his fame, among other things,

a On Narrative Medicine terminology Dr. Rita Charon states: The "native medicine" phase came to me as a unifying designation to signify clinical practice based on the theory and performance of reading, writing, narrating, and receiving stories. The name appealed to me because, as a nominal phrase, it points to a "thing" and not to an idea (complying with the opinion of William Carlos Williams that there is no an idea but a thing) and implies a type of practice together with a set of conceptual realities in which it nests

b A term proposed by Dans to exemplify the barrier that must separate doctors from patients, the same that "must be thick enough to prevent us from living and dying with the disease of all patients and thin enough to be sensitive to their sufferings, needs and feelings". In: Dans PE. Doctors in the movies: boil the water and say "Aah". Bloomington, IN: Med-Ed Press; 2000. In Baños, J. What should be the thickness of the shield? Teaching the subtleties of the doctorpatient relationship through literary works and commercial films. Rev Med Cine 3 (2007): 159-165 
to his great academic production, among which he has biographies studied from a medical point of view and which appear in The Count-duke of Olivares or Amiel. Paco Maglio and the study of the bridges between biology and biography, contained in his book The dignity of other, or Luis Chiozza and his phytopathological vision set out in volume XIV of Why do we get sick? Furthermore, one of the most popular exponents within this field is Oliver Sacks, with works such as Awakenings ${ }^{c}$, The man who mistook his wife for a hat, Hallucinations, among others. The list could go on, but our intention is only to show an outline of authors that provide the interested reader with the incentive to start their own search.

Below, two narrations are transcribed in order to get a little bit closer to understanding what a Medical Narrative consists of:

\section{Story 1}

Mrs. Ruby Nelson is an 82-year-old obese, diabetic, hypertensive and osteoarthritis woman who has been in my care for 15 years. Our first years together were marked by disagreement over little things: she insisted on brand name drugs, even when generics were just as good, and I was furious about their cost. She never took seriously the need to address her obesity. Consequently, her diabetes was poorly controlled, and her degenerative knee disease became incapacitating. One afternoon, while sitting at the exam table waiting for her blood pressure to be taken (which was invariably alarming and caused me anxiety, fear, great impatience and the sense of duty to scold), she mentioned that she sang in the church choir. I don't know why, but I asked her to sing me a hymn. This woman, whose body biotype she usually described as "morbidly obese", transformed into an image full of majesty and dignity when she raised her heavy head, clasped her hands and sang in a deep height, above the Lord, on the banks of the river leading her home. From then on, I would do anything for her and she for me. A moment of epiphany without a doubt, those few chords of a sad and powerful song transported us to a new geography of respect to value ourselves together.

Since then, she has developed her cerebrovascular disease, which has required multiple hospitalizations to rule out strokes. She has stood before me, during her multiple weeks in the hospital, as a figure of great dignity and spirituality. Despite strong recommendations from social workers and nurses regarding placing her in a nursing home, I supported her deep desire to return to her own apartment, knowing now something about the power of her wishes. Now she is back home, anticoagulated, her blood pressure effectively controlled, and TIAs are absent now. She continues to ask me to do her small favours, and I am always grateful that she asks me to do so ${ }^{4}$.

\section{Story 2}

I knew that an MRI - which provides extraordinary images of the brain - would be better than CT to capture subtle abnormalities. I was very clear that we needed more clarity on Jim's situation, redundancy being worth it, so I requested the resonance as soon as he had stabilized. A little calmer, I went to visit the next patient.

An hour later, I was finishing the paperwork in my office and received a call from the MRI technician.

"Doctor Castaldo," Gloria said hastily, "this patient of yours, Reilly, is doing a scene of a thousand devils down here." He does not want me to do the MRI, can you prescribe him a sedative?

My first reaction was to say, "Sure, give him ten milligrams of Valium." But I hesitated. There were some things that didn't add up.

c This book was brought to the big screen in 1990 with Robin Williams and Robert De Niro as protagonists. Its plot is based on the experiences and relationships that Oliver Sacks had with patients suffering from lethargic encephalitis (also called sleeping sickness) and their surprising awakening in 1969 when he administered L-dopa to them at Mount Carmel Hospital, New York. 
-Why doesn't he want it done? -I asked.

"He says that if we put him inside the resonance unit, he will burn," Gloria explained, hinting at a certain sarcasm.

-Will he burn? I asked confused. A kind of sunburn?

"No," Gloria replied. He refers to "burning" as if it were a deadly conflagration. He says we can't get an MRI because he has Persian tattoos.

-Persian tattoos? I repeated incredulously. At the time, not only was I puzzled, but I was beginning to feel frustrated and fed up.

[...] "But what if he was right?" the little voice insisted inside my head [...] I dragged the chair to the computer, typed in the name of the initial Medline bibliographic search page and wrote: "Tattoo and MRI". [...] The computer was thinking forever. At last a strange reference suddenly came out translated from German and published in 1986. It was titled: "Persian iron tattoos and risk of third degree burn during MRI." I was speechless. [...] I picked up the phone and called the resonance unit to stop the test.

[...] The truth is that I had been about to kill a man because of my ignorance. I should have believed Jim from the first moment. But I did not. [...] But, in addition, I had not listened to Jim because I believed that, in a way, my colleagues and I monopolized all medical wisdom ${ }^{9}$.

As we can see, stories and narratives are not inert texts but have the essence of their protagonists, allowing those who do not have a voice to have one, giving words and meaning to imposed silences, voluntarily or involuntarily. It allows us to interpret others without being them (and to question and evaluate ourselves as well). They remind us that we are mortal and that we depend on others. As Levinas pointed out: "I am not the other, but I need the other to be me" ${ }^{2}$.

Doctors are only such thanks to their patients. Health cannot be understood except through contact with disease. This is the strength of Narrative Medicine, allowing to better understand the other, loosening what does not tie our idea of being separate individuals instead of interrelated. Nobody constitutes themselves; one is only in relation to the other. Recalling the story of the source Moira, Ananke, Andrzej Szczeklik comments that she spreads her nets from heaven to earth, imprisoning the entire human race, gradually squeezing and suffocating everyone, but that this panorama that seems so discouraging, is not so if we help each other:

"[But] The etiology teaches us that in the name of Ananke the ideas of "constriction" and "kinship" also resonate. Perhaps the word "link" illustrates this double semantic meaning well. On the other hand, the Ananke voice is considered by others to be close to the expression 'take in arms'. This duplicity, or even contradiction, is reflected in the net of Necessity that inevitably narrows around man when the world is shattered, when he flees in all directions. But the oppression of the network is loosened when we discover the links that unite us to other people, and its thread becomes a thread of understanding, sympathy and trust ${ }^{10}$.

Well, why not to use Narrative Medicine to try to loosen the threads that put pressure on the sick and us? Many doctors are already walking this path. It is relevant to instruct new doctors in these techniques that promote their training while giving them the privilege of healing. Likewise, for those who have already passed the stage of their formal education, it is a good opportunity to investigate the possibilities of a more humane encounter with patients. 


\section{References}

1. Han B. La sociedad del cansancio. Barcelona, España: Editorial Herder; 2012

2. Maglio P. La Dignidad del Otro. Puentes entre la biología y la biografía. Buenos Aires, Argentina: El Zorzal; 2011.

3. Barcia R. Diccionario general etimológico de la lengua española. Tomo V. 1875. In: Maglio P. La Dignidad del Otro. Puentes entre la biología y la biografía. Buenos Aires, Argentina: El Zorzal; 2011

4. Charon R. Narrative medicine. Honoring the Stories of Illness. New York: Oxford University Press; 2006.

5. Foucault M. El nacimiento de la clínica. Una arqueología de la mirad médica. Buenos Aires: Siglo Veintiuno. Vigésimo segunda edición. 2006.

6. Sacks O. Despertares. Barcelona: Anagrama. Sexta edición; 2005. Pp 533.

7. Avila J. El caso en narrativa como didáctica para la educabilidad en estudiantes de medicina. Anuario Digital Investigación Educativa. 2018; 1: 359-366.

8. Pino AR, Páez IJ. Medicina Narrativa, un complemento de la Historia clínica formal. Rev Fac Cien Méd. 2017; 35(2): 60-64

9. Levvit L, Castaldo J. El hombre con el tatuaje de hierro. Los médicos aprenden de sus pacientes. Plataforma Editorial: Barcelona; 2009.

10. Szczeklik A. Catarsis. Sobre el poder curativo de la naturaleza y del arte. Barcelona: Acantilado; 2013. 